\title{
Proceeding
}

Supplementary Issue: Autumn Conferences of Sports Science. Costa Blanca Sports Science Events, 18-19 December 2020. Alicante, Spain.

\section{Influence of physical working capacity on quality of life and life satisfaction in old-age population of Ukraine}

\author{
ANNA HAKMAN 14 , OLENA ANDRIEIEVA2 ${ }^{2}$, VITALII KASHUBA², SVITLANA DUDITSKA ${ }^{1}$, PETRO \\ HORIUK¹, INNA KHRYPKO², YULIIA TOMILINA ${ }^{3}$, OLENA KLJUS ${ }^{4}$, TARAS LUKASHIV1 \\ ${ }^{1}$ Yuriy Fedkovych Chernivtsi National University, Ukraine \\ ${ }^{2}$ National University of Physical Education and Sport, Ukraine \\ ${ }^{3}$ Kyiv National Economic University named after Vadym Hetman, Ukraine \\ ${ }^{4}$ Kamianets-Podilsky Ivan Ohienko National University, Ukraine
}

\begin{abstract}
The aim of this study was to examine relationship between indicators of physical working capacity and levels of satisfaction and quality of life in older adults. Materials and methods. This study involved 221 elderly participants including 152 women and 69 men with an average chronological age of 67.1 years. The study was conducted at the University of Third Age (Chernivtsi, Ukraine) during the years 2019-2020. Research methods: assessment of physical working capacity, Questionnaire survey with Medical Outcomes Study-Short Form (SF-36), measurement of Life Satisfaction Index (Neugarten A.O.), and statistical analysis. Results. The degree of relationship between indicators of physical performance and levels of satisfaction and quality of life was determined in older adults. It was found that physical working capacity is moderately associated with all indicators of life satisfaction; all correlation coefficients were significant at the level $a=.05$. Conclusions. For this age group, among the indicators of the physical component of health, the most significant one was Physical Functioning (34.36 \pm 1.8 points), and in the mental component of quality of life, the most significant was Vitality (59.34 \pm 1.8 points). Among the respondents, $68.2 \%$ had low level of life satisfaction and $25.3 \%$ had average level. We found a close relationship between these parameters. Physical working capacity is closely related to the quality of life indicators such as Physical Functioning (0.664), Overall.mood.background (0.581), and Vitality (0.524).

Keywords: Old age; Physical activity; Quality of life; Life satisfaction.
\end{abstract}

\section{Cite this article as:}

Hakman, A., Andrieieva, O., Kashuba, V., Duditska, S., Horiuk, P., Khrypko, I., Tomilina, Y, Kljus, O., \& Lukashiv, T. (2021). Influence of physical working capacity on quality of life and life satisfaction in old-age population of Ukraine. Journal of Human Sport and Exercise, 16(2proc), S202-S211. doi:https://doi.org/10.14198/ihse.2021.16.Proc2.05

Corresponding author. Yuriy Fedkovych Chernivtsi National University, Ukraine. https://orcid.org/0000-0002-7485-0062

E-mail: an.hakman@chnu.edu.ua

Abstract submitted to: Autumn Conferences of Sports Science. Costa Blanca Sports Science Events, 18-19 December 2020. Alicante, Spain.

JOURNAL OF HUMAN SPORT \& EXERCISE ISSN 1988-5202

(c) Faculty of Education. University of Alicante

doi:10.14198/jhse.2021.16.Proc2.05 


\section{INTRODUCTION}

The constant increase in the proportion of the elderly is one of the most important challenges for most countries in the world. In 2020, there are an estimated 727 million persons aged 65 years or over worldwide. This number is projected to more than double by 2050 , reaching over 1.5 billion persons. The share of older persons in the global population is expected to increase from 9.3 per cent in 2020 to 16.0 per cent in 2050 (Azam Jafari, Nayyereh Aminisani, Seyed Morteza Shamshirgaran, Laven Rastgoo \& Neda Gilani, 2020; Hapala, Eero, Lee, Earric \& Laukkanen, Jari, 2020; WHO, https://www.un.org/development/desa/pd/sites/www.un.org.development.desa.pd/files/files/documents/202 0/Sep/un_pop_2020_pf_ageing_10_key_messages.pdf. In different countries this increase fluctuates from $25 \%$ to $50 \%$. Due to the growing aging of the population, of great importance are the practical aspects of gerontology: the prevention of diseases in older adults, addressing the issues of their work and rest, and search for means of physical activity that can significantly improve the health of the elderly.

Physical working capacity is an integral expression of human capabilities. Research conducted in recent years in Ukraine and other countries have shown that there is a relationship between physical working capacity and health. Furthermore, this relationship can be traced even in school-age children (Galan, Andrieieva \& Yarmak, 2019).

Physical working capacity is the ability of the body to perform muscular work of moderate intensity for a long time. This ability is an important component of physical fitness. It is closely correlated with the main indicators of physical fitness: working capacity, health condition, and physical perfection. Low working capacity is related to a decrease in reserve capacity of the body which is manifested in the conditions of intense muscular activity, limited oxygen supply, maximum myocardial oxygen consumption, and intensity of vascular responses (Pavlova lu. Vovkanych L, \& Vynogradskyi B., 2014; Rodrigo Gomes De Souza Vale, Dirceu Ribeiro Nogueira Da Gama, Flávio Boechat De Oliveira, Denize Sá De Mendonça Almeida, Juliana Brandão Pinto De Castro, Edgar Ismael Alarcon Meza, Rafael Da Silva Mattos \& Rodolfo De Alkmim Moreira Nunes, 2018).

The term 'quality of life' is gaining recognition and is used in the process of forming a humanistic social policy and addressing its problems given the need for human adaptation to changing conditions (Park, S. G., 2006; Theofilou, P., 2013; Andrieieva, O. Hakman, A., Kashuba, V., Vasylenko, M., Patsaliuk, K., Koshura, A., \& Istyniuk, I., 2019). Quality of life is assessed in terms of degree of satisfaction of objective needs and interests, as well as subjective satisfaction with the quality of life (Hakman Anna, Olena Andrieieva, Vitalii Kashuba, Tetiana Omelchenko, Carp Ion, Vladyslav Danylchenko, \& Ksenia Levinskaia, 2019; Harahousou, Y., \& Kabitsis, C., 2002; Barbosa BT, Santos RL, Chaves AB, Brindeiro-Neto W, Pereira T, Silva Al \& Soares LI, 2019).

The quality of life is an integral characteristic that is formed by the physical, social and psychological functioning of the individual. The WHO defines the quality of life as an individual's comparison of their position in society in the context of culture and value system with their plans, opportunities, and degree of dissatisfaction (Monteiro, António M., Silva, Pedro, Forte, Pedro, \& Carvalho, Joana, 2019; WHO).

The aim of this study was to determine relationship between indicators of physical performance and levels of satisfaction and quality of life in older adults. 


\section{MATERIALS AND METHODS}

\section{Participants}

This study involved 221 elderly participants including 152 women and 69 men with an average chronological age of 67.1 years.

\section{Organization}

The study was conducted at the University of Third Age (Chernivtsi, Ukraine) during the years 2019-2020.

\section{Physical working capacity}

The $\mathrm{PWC}_{150}$ test includeв assessment of individual's power output at a standard load, at which heart rate $(\mathrm{HR})$ reaches $150 \mathrm{bpm}$ and is the maximum for old age people. The $\mathrm{PWC}_{150}$ test of assessing physical working capacity is based on the linear relationship between heart rate and power output. Heart rate of 150 bpm reflects the optimal mobilization of the heart's capacities in old age, as the maximum stroke volume of the heart can still be maintained upon it. Furthermore, the linear relationship between heart rate and power output is maintained up to the heart rate of $150 \mathrm{bpm}$ in this age group. To assess the power output at a heart rate of $150 \mathrm{bpm}$, the subjects performed the work task 2 times for 5 minutes with different power output (on the Fitex A800 ergometer). The value of physical working capacity, at a variable age of heart rate, was calculated using the same formula as $\mathrm{PWC}_{150}$, but taking into account the age limits of the maximum heart rate:

$$
\mathrm{PWC}_{150}=\mathrm{W}_{1}+\left(\mathrm{W}_{2}-\mathrm{W}_{1}\right)\left(150-\mathrm{HR}_{1}\right) /\left(\mathrm{HR}_{2}-\mathrm{HR}_{1}\right)
$$

Where:

$W_{1}$ is power output at the first work task;

$W_{2}$ is the power output at the second work task;

$\mathrm{HR}_{1}$ is the heart rate during the last minute of the first work task;

$\mathrm{HR}_{2}$ is the heart rate during the last minute of the second work task.

\section{Quality of life}

Questionnaire survey with Medical Outcomes Study-Short Form (SF-36). SF-36 comprises 36 questions which are grouped into eight scales: physical functioning, usual role functioning, bodily pain, general health, vitality, social functioning, emotional state, and mental health. The scores for each scale are summed in such a way that the higher scores (from 0 to 100 ) represent better value for the given domain. Then two component scores can be derived: a mental component and a physical component of health.

\section{Life satisfaction}

The Life Satisfaction Index (Neugarten A.O.) was developed by a group of American researchers dealing with socio-psychological problems of gerontopsychology. The instrument was translated and adapted by N.V. Panina. The questionnaire consists of 20 questions, the scores of which are summed for 5 scales, which describe various aspects of the general psychological state and life satisfaction of an individual. This survey instrument is used to assess the most general psychological state of an individual which is dependent on their own characteristics and the structure of attitudes to different aspects of life. Life satisfaction index is a multifaceted indicator that evaluates the emotional component as the main component. The index of general life satisfaction is calculated using a scoring key. The maximum value of Life Satisfaction Index is 40 points. The average values of life satisfaction are 25-30 points. Scores below 25 are considered low. 
Statistical analysis.

Student's $t$-test was used to assess the statistical significance. Statistical processing of the results was performed using Statistica 6.0 (StatSoft, USA) and Excel 2003 spreadsheets (Microsoft, USA).

Spearman correlation coefficient was used to assess the relationship between physical performance and life satisfaction. As a measure of the association between variables, the Pearson correlation coefficients were calculated for indicators of physical performance and quality of life of the elderly. In each case, the hypothesis $\mathrm{H}_{0}: \rho=0$ vs. $\mathrm{H}_{1}: \rho \neq 0$ was tested and $p$-value was calculated. All statistical tests were done at the 05 level of significance. Data were processed using the free and open source environment RStudio.

\section{RESULTS}

When assessing the quality of life, the opinion of the respondents is of the greatest importance, which reflects and correlates all the objective and subjective factors that determine their quality of life. The subjectivity of the assessment of quality of life parameters, in particular its components characterise the emotional state of a person, personality traits, type of higher nervous activity, and social circumstances (Table 1).

Physical activity parameters indicate that the respondents' subjective assessment of the volume of physical activity, which is not limited by the health state, was $34.36 \pm 1.8$ points out of 100 possible during the experiment. As for the parameter of bodily pain, it reaches the value $32.9 \pm 1.4$. In our opinion, this is primarily due to the fact that the elderly are quite sensitive and it is very important for them to feel safe for their own health.

Table 1. Quality of life of the study participants $(n=221)$

\begin{tabular}{llcc}
\hline Quality of life components (SF-36) & Scale & $\mathbf{X}$ & $\mathbf{~ m}$ \\
\hline \multirow{4}{*}{ Physical component of health } & Physical Functioning & 34.36 & 1.8 \\
& Role-Physical Functioning & 25.67 & 2.8 \\
& Bodily pain & 31.44 & 2.5 \\
& General Health & 32.9 & 1.4 \\
& Vitality & 59.34 & 1.8 \\
Mental component of health & Social Functioning & 21.41 & 0.4 \\
& Role-Emotional & 19.50 & 1.8 \\
& Mental Health & 35.17 & 1.2 \\
\hline
\end{tabular}

The feeling of satisfaction with life in old age appears as an important indicator of an individual's physical health, which is manifested in their interest in life and the content of later life. General assessment of the quality and content of life in old age is reflected in the emotional feeling of satisfaction with life. Factors influencing life satisfaction and success of adaptation in old age include: health, financial position, marital status, optimal functioning, relationships with the outside world, and even the ability to drive a car.

With an inner perception of their age, a meaningful and productive life, an interest in their own health and communication, appropriate physical and work activities, the lives of the elderly will be full, and they will feel happy and satisfied.

We conducted an assessment of the life satisfaction index (LSI) among 221 people aged 60-75 years. According to the LSI assessment, most respondents (68.2\%) have a low level of life satisfaction, which indicates that they lack enthusiasm for everyday life, passively accept own failures, and see bad luck as a 
given. Furthermore, they are insecure and have low self-esteem, and thus can not enjoy life. They are dissatisfied with their health and various activities. An average level of life satisfaction was found in $25.3 \%$ of respondents. This group of subjects realistically assess their own internal and external factors, health state, and have adequate self-esteem. They treat everyday life well, but do not feel completely satisfied with life. They adequately evaluate their physical capabilities, but do not take the initiative to change something and to improve their physical condition, and do not try to make their leisure time more diverse through physical activity. Only $6.5 \%$ of respondents have a high level of LSI.

Without information about the physical working capacity of the subjects, it is not possible to judge the state of health, social hygienic and social economic living conditions of older adults. An assessment of physical working capacity of study participants showed that $3.3 \%$ of them had a high level and $6.6 \%$ had a higher than average level of working capacity (Figure 1).

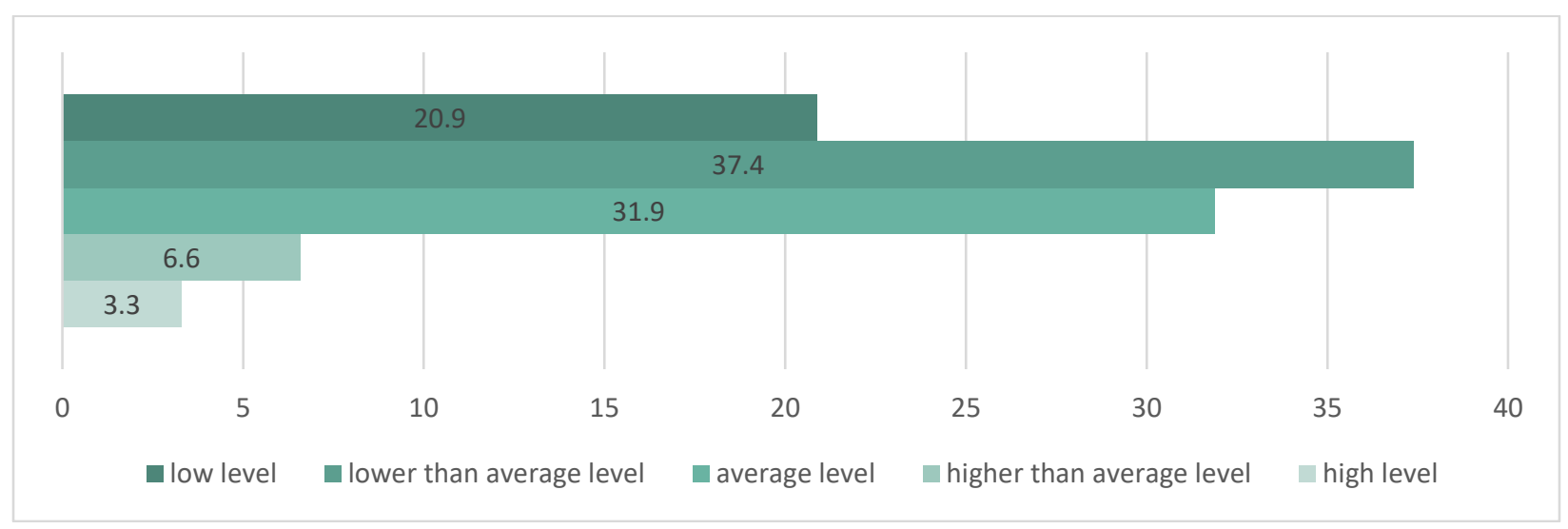

Figure 1. Distribution of study participants by level of physical working capacity, $\%(n=221)$

During the study, we found a correlation between physical working capacity and quality of life in older adults (Figure 2).

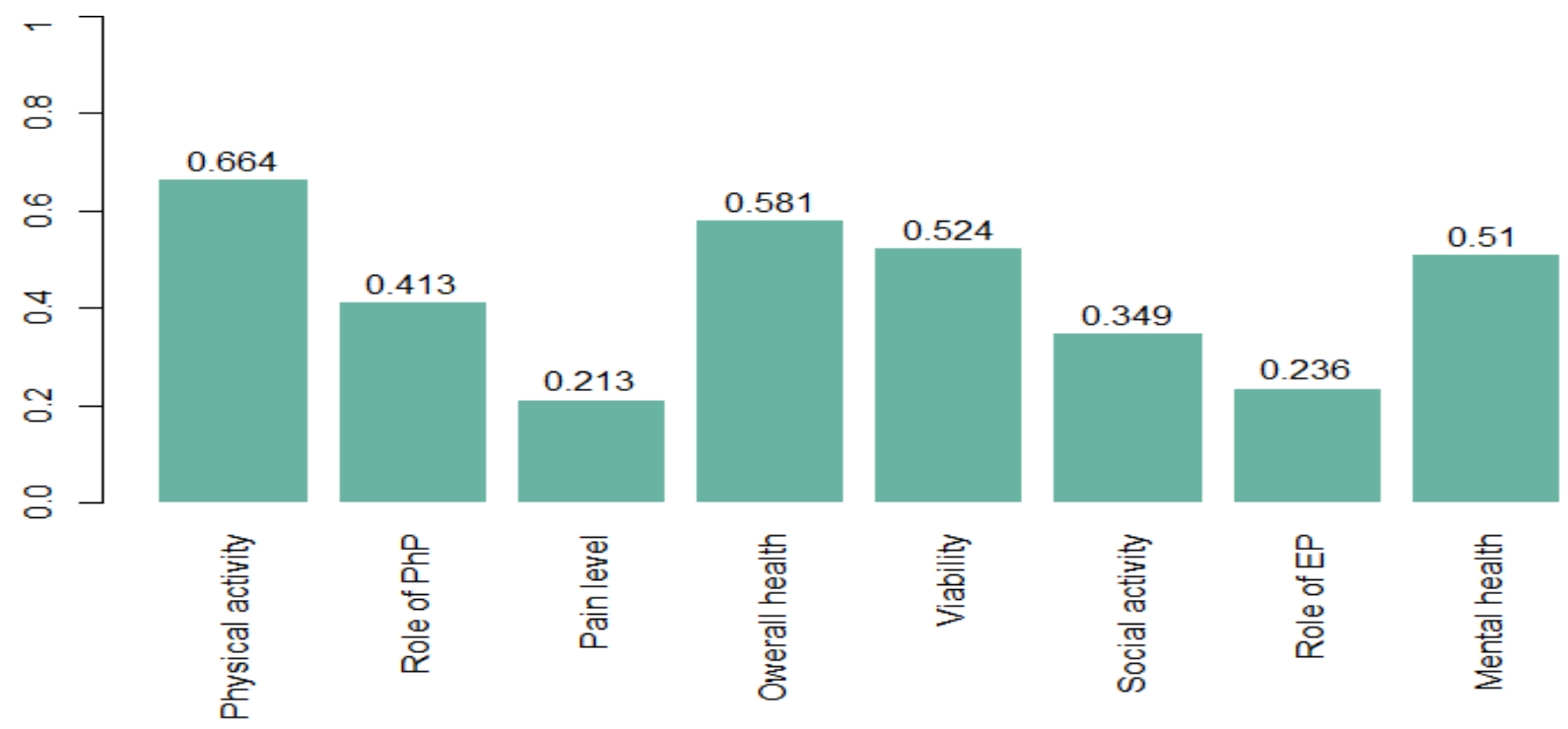

Figure 2. Correlation between physical working capacity and indicators of quality of life in older adults $(n=221)$ 
Physical performance is moderately correlated with all variables in the Life satisfaction domain (Table 2).

Table 2. Correlation between physical working capacity and life satisfaction in older adults $(n=221)$.

\begin{tabular}{llll}
\hline Parameter 1 & Parameter 2 & $\begin{array}{l}\text { Spearman correlation } \\
\text { coefficient }\end{array}$ & p-value \\
\hline PhisDis.num & Interest in life & .319 & $.002088^{* * *}$ \\
PhisDis.num & Consistency in achieving goals & .320 & $.001983^{* * *}$ \\
PhisDis.num & Consistency between goals and objectives & .357 & $.0005158^{* * *}$ \\
PhisDis.num & Overall mood background & .358 & $.0004974^{* * *}$ \\
PhisDis.num & Life Satisfaction Index Num & .370 & $.0003058^{* * *}$ \\
\hline
\end{tabular}

All correlation coefficients were significant at the level $\alpha=.05$.

\section{DISCUSSION}

In recent years, a number of studies have reported the positive effects of physical activity on slowing the aging process. Moderate physical activity improves the functions of the cardiorespiratory system affected by disease and increases their reserves (Bianco, et al, 2019). Physical exercise can have a positive effect on metabolism (Drozdovska, et al, 2020). Regular exercise increases the body's tolerance to adverse environmental factors and improves resistance to disease. According to studies conducted in countries with a high level of involvement of the population in physical activity, from $50 \%$ to $70 \%$ of the population over 65 years of age assess their health as good or satisfactory. However, it is important to take into account that the aging of Ukrainian population under unfavorable social economic and environmental conditions is accompanied by a decrease in physical activity, a sharp deterioration in health, and a catastrophic increase in the number of chronically ill people.

According to our study, life satisfaction in the elderly is depend on the relationships within the family and the presence of friends and a socially important group. In particular, Pavlova lu. Vovkanych L, \& Vynogradskyi B. (2014) report that life satisfaction is influenced by social economic factors (income and well-being), marital status, physical activity, and health.

It has been found that there are gender differences in the feeling of satisfaction with life in older adults (Theofilou, P., 2013; Hapala, Eero, Lee, Earric \& Laukkanen, Jari., 2020). For example, women are more likely to report psycho-emotional manifestations and dissatisfaction with their own health. In particular, the attitude to own helplessness and morbidity in old age is dependent on gender. Women focus more on their own health, visit doctors often, and complain about their illnesses.

Sirgy, M. J., Michalos, A. C., Ferriss, A. L., Easterlin, R. A., Patrick, D., \& Pavot, W. (2006) identified a number of relationships, many of which are prognostic. Life satisfaction is affected by health: healthier people are happier than people who have health problems. Life satisfaction was found to be associated with marital status: married people are significantly more satisfied with life than single people. Association of life satisfaction with income level was also identified (Yelizarova, O, Stankevych, T, Parats, A, Antomonov, M, Polka, N, \& Hozak, S., 2020).

Life satisfaction is a complex integrated concept that accumulates many factors and aspects. Hakman A. (2019) believes that the factors influencing life satisfaction include the following: personal and family safety; material well-being; family well-being; setting creative goals; creative self-realization; fruitful leisure; good 
social climate; decent social status; effective informal social contacts; social stability, confidence in the future; comfortable living environment; and good health.

We confirmed the data on the deterioration of some indicators of quality of life with age that were reported by Yelizarova et al. (2020). Such changes reflect the deterioration of physical and mental health that occurs with age and the global trend towards an increase in the number of people with chronic diseases. Similar data on the relationship between health and physical working capacity, physical activity, and morphofunctional indicators in middle-aged men and women were reported by Haapala et al. (2020) and Monteiro et al. (2020).

Researchers emphasize the close association between quality of life and level of physical working capacity of older persons. For example, Yu. Pavlova et al. (2014) found that participation in health-enhancing and recreation activities can improve (up to 1.6 times) the quality of life of older and oldest-old persons, in particular, by increasing the level of physical working capacity. Improvements in quality of life were observed on the scales that measure the amount of daily physical activity, mood, and social activity. Our research confirmed these results.

The findings of our study of the relationship between physical working capacity and quality of life of older people makes contributions to, clarifies and extends the theoretical and methodological knowledge on the formation, support, and improvement of quality of life in this age group. Increasing the level of physical activity of older persons through active leisure provides an opportunity to adapt to changes in the environment, promotes social integration, and improve quality of life and life satisfaction (Shim, Yu-Jin, Choi, Ho-Suk, Shin, Won-Seob, 2019).

The current findings are important for designing special health-enhancing and recreational programs aimed at improving the quality of life. Physical activities should be organized based on the recommendations of Ahn, Yong-Duk \& Shin, Jeong-Hun on differences in levels of physical loads for the older and oldest-old persons and of Şahin, Gülşah \& Coşkun, Ali \& Apaydin, Serap. (2018) on the impact of physical activity on the indicators of functional condition and physical fitness of older-age women.

\section{CONCLUSIONS}

This study has determined physical working capacity of older adults. Lower than average (37.4\%) and average $(31.0 \%)$ levels of physical working capacity prevailed among the respondents. The quality of life has been also determined in older persons. For this age group, among the indicators of the physical component of health, the most significant one was Physical Functioning (34.36 \pm 1.8 points), and among the mental component of quality of life, the most significant was Vitality (59.34 \pm 1.8 points). Among the respondents, $68.2 \%$ had low level of life satisfaction and $25.3 \%$ had average level. We found a close relationship between these parameters. Physical working capacity is closely related to the indicators of quality of life such as Physical Functioning (0.664), Overall.mood.background (0.581), and Vitality (0.524). However, physical working capacity was found to be associated with all indicators of life satisfaction. All correlation coefficients were significant at the level $\alpha=.05$.

\section{DISCLOSURE STATEMENT}

There were no conflicts of interest. 


\section{REFERENCES}

Ahn Y.-D. \& Shin J.-H. (2019). A Study on the differences in senior fitness levels for health life in the elderly women. Journal of the Korea Entertainment Industry Association, 13, 367-375. https://doi.org/10.21184/jkeia.2019.12.13.8.367

Andrieieva O. \& Hakman A. (2020). Main directions of optimization of recreation and health activities of the elderly. Scientific Journal of National Pedagogical Dragomanov University. Series 15. Scientific and Pedagogical Problems of Physical Culture (physical Culture and Sports). 1(121), 7-10. https://doi.org/10.31392/NPU-nc.series15.2019.1(121)20.01

Andrieieva, O., Hakman, A., Kashuba, V., Vasylenko, M., Patsaliuk, K., Koshura, A., \& Istyniuk, I. (2019). Effects of physical activity on aging processes in elderly persons. Journal of Physical Education and Sport. 1308-1314. https://doi.org/10.7752/jpes.2019.s4190

Martínez-Vidal A., Martínez A. P., Pereira M. del P. D. \& Martínez-Patiño M. J. (2011). Effect of a combined program of physical activity and intellectual activity in the cognitive functioning of the elderly. Journal of Human Sport \& Exercise, 6(2), pp. 462-473. https://doi.org/10.4100/jhse.2011.62.27

Jafari A., Aminisani N., Shamshirgaran S. M., Rastgoo L. \& Gilani N. (2020). Predictors of mobility limitation in older adults: A structural equation modeling analysis. Baltic Journal of Health and Physical Activity, 12 (1): 20-31. https://doi.org/10.29359/BJHPA.12.1.03

Barbosa BT, Santos RL, Chaves AB, Brindeiro-Neto W, Pereira T, Silva Al \& Soares LI et al. (2019). Self-related quality of life of elderly submitted to a 12-week aquatic training program. Journal of Human Sport and Exercise, 14(2), 281-291. https://doi.org/10.14198/ihse.2019.142.03

Bazin, F., Noize, P., Dartigues, J. F., Ritchie, K. A., Tavernier, B., Moore, N., Pariente, A., \& FourrierReglat, A. (2012). Engagement in leisure activities and benzodiazepine use in a French communitydwelling elderly population. International Journal of Geriatric Psychiatry, 27(7), 716-721. https://doi.org/10.1002/gps.2773

Bianco, A., Napoli, G., Pasquale, M. di, Filippi, A.R., Gómez-López, M., Messina, G., lovane, A. \& Tabacchi, G. (2019). Factors associated with the subjective health complaints among adolescents: Results from the ASSO Project. Journal of Human Sport and Exercise. 14(2), 443-455. https://doi.org/10.14198/ihse.2019.142.16

Boulton ER, Horne M \& Todd C. (2018). Multiple influences on participating in physical activity in older age: Developing a social ecological approach. Health Expect, 21(1):239-48. https://doi.org/10.1111/hex.12608

Buettner, I. L., \& Fitzsimmons, S. (2002). AD-venture program: therapeutic biking for the treatment of depression in long-term care residents with dementia. American Journal of Alzheimer'S Disease and Other Dementias,17(2), 121-127. https://doi.org/10.1177/153331750201700205

Depp, C. A., \& Jeste, D. V. (2006). Definitions and predictors of successful aging: A comprehensive review of larger quantitative studies. American Journal of Geriatric Psychiatry,14(6), 6-20. https://doi.org/10.1097/01.JGP.0000192501.03069.bc

Drozdovska, S., Andrieieva, O., Yarmak, O., \& Blagii, O. (2020). Personalization of health-promoting fitness programs for young women based on genetic factors. Journal of Physical Education and Sport, (1), 331-337. https://doi.org/10.7752/ipes.2020.s1046

Federici A., \& Palanca R. (2019). Home-fitness: physical exercise and elderly's quality of life. Journal of Physical Education and Sport, Vol 19 (Supplement issue 5), pp 1852 - 1855

Galan Y., Andrieieva O., \& Yarmak O. (2019). The relationship between the indicators of morphofunctional state, physical development, physical fitness and health level of girls aged 12-13 years. Journal of Physical Education and Sport, 19, 1158-1163. https://doi.org/10.7752/jpes.2019.02168 
Hakman A., Andrieieva O., Kashuba V., Omelchenko T., Ion C., Danylchenko V., \& Levinskaia K. (2019) Technology of planning and management of leisure activities for working elderly people with a low level of physical activity. Journal of Physical Education and Sport, Supplement Issue 6, 2159-2166.

Hakman, A. (2019) Structure of the incidence of older people in a demographic context. Slobozhanskyi Herald of Science and Sport, Vol. 7 No. 5(73), pp. 35-37. https://doi.org/10.15391/snsv.2019-5.015

Hakman, A., Andrieieva, O., Kashuba, V., Nakonechnyi, I., Cherednichenko, S., Khrypko, I., Tomilina, Yu. \& Filak F. (2020). Characteristics of Biogeometric Profile of Posture and Quality of Life of Students During the Process of Physical Education. Journal of Physical Education and Sport (JPES), Vol. 20(1), P. 79-85.

Hapala, E., Lee, E. \& Laukkanen, J. (2020). Associations of cardiorespiratory fitness, physical activity, and BMl with arterial health in middle-aged men and women. Physiological Reports. 8. https://doi.org/10.14814/phy2.14438

Harahousou, Y., \& Kabitsis, C. (2002). European models of leisure policies and physical activity programs for elderly people. World Leisure Journal, 44(1), 3-10. https://doi.org/10.1080/04419057.2002.9674255

Hinterlong, J. E. (2006). Race disparities in health among older adults: examining the role of productive engagement. Health and Social Work,31(4), 275-288. https://doi.org/10.1093/hsw/31.4.275

ledynak G., Galamandjuk L., Kyselytsia O., Nakonechnyi I., Hakman A. \& Chopik O.(2017). Special aspects of changes in physical readiness indicators of young men with different somatotypes between 15 and 17 years of age.Journal of Physical Education and Sport, 17(4), 2690 - 2696.

Kashuba, V., Andrieieva, O., Goncharova, N., Kyrychenko, V., Karp, I., Lopatskyi, S., \& Kolos, M. (2019). Physical activity for prevention and correction of postural abnormalities in young women. Journal of Physical Education and Sport, Supplement issue, 19(2), 500-506. https://doi.org/10.7752/jpes.2019.s2073

Kozina, Z., lermakov, S., Bartík, P., Yermakova, T. \& Michal, J. (2018), «Influence of self - regulation psychological and physical means on aged people's functional state», Journal of Human Sport and Exercise, No. 13(1), pp. 99-115. https://doi.org/10.14198//hse.2018.131.10

Márcio F. R., Santana J. O., Gusmão N., França E. de, Carvalho B. N., Farinazo K. B., Bonorino S. L., Corralo V., Sá C. A. de \& Caperuto E. C. (2019). Effects of strength training with and without blood flow restriction on quality of life in the elderly. Journal of Physical Education and Sport, Vol 19 (Supplement issue 3), pp 787-794. https://doi.org/10.7752/jpes.2019.01078

Monteiro, A. M., Silva, P., Forte, P., \& Carvalho, J. (2019). The effects of daily physical activity on functional fitness, isokinetic strength and body composition in elderly community-dwelling women. Journal of Human Sport and Exercise. 14(2), 385-398. https://doi.org/10.14198/jhse.2019.142.11

Park, S. G. (2006). The relationship between elderly people's mental health and quality of life. Korean Journal of Health Psychology, 11(4), 785-796.

Park, S. J. (2004). The causal model building study for leisure diagnostic battery, flow experience by leisure sports participants. Journal of Korean Physical Education Association for Girls and Women 18(3), 153-164.

Pasichnyk V., Pityn M., Melnyk V., Karatnyk I., Hakman A., \& Galan Y. (2018). Prerequisites for the physical development of preschool children for the realization of the tasks of physical education. PhysicalActivityReview, vol. 6, 117-126. https://doi.org/10.16926/par.2018.06.16

Pavlova lu., Vovkanych L, \& Vynogradskyi B. (2014) Physical activity of elderly people. Fizjoterapia, 22(2): 33-39. https://doi.org/10.1515/physio-2014-0012

Pavlova Yu. (2015). The structure of the quality of life of the population. Slobozhansky scientific and sports bulletin. 2015; 5 (49): 90-4. https://doi.org/10.15391/snsv.2015-5.015 
Ruiz-Montero P. J. \& Castillo-Rodríguez A. (2016). Body composition, physical fitness and exercise activities of elderly. Journal of Physical Education and Sport, 16(3), pp. $860-865$.

Vale R. G. de S., Gama D.R.N. da, Oliveira F.B. de, Almeida D.S. de M., Castro J. B. P. de, Meza E. I. A., Mattos R. da S. \& Nunes R. de A. M. (2018). Effects of resistance training and chess playing on the quality of life and cognitive performance of elderly women: a randomized controlled trial. Journal of Physical Education and Sport, 18(3), pp. 1469 - 1477.

Shim, Y.-J, Choi, H.-S., \& Shin, W.-S. (2019). Aerobic training with rhythmic functional movement: Influence on cardiopulmonary function, functional movement and Quality of life in the elderly women. Journal of Human Sport and Exercise. 14(4), 748-756. https://doi.org/10.14198//hse.2019.144.04

Silverstein, M., \& Parker, M. G. (2002). Leisure activities and quality of life among the oldest old in Sweden. Research on Aging, 24(5), 528-547. https://doi.org/10.1177/0164027502245003

Sirgy, M. J., Michalos, A. C., Ferriss, A. L., Easterlin, R. A., Patrick, D., \& Pavot, W. (2006). The qualityof-life (QOL) research movement: past, present, and future. Social Indicators Research, 76(3), 343466. https://doi.org/10.1007/s11205-005-2877-8

Steger, M. F., Frazier, P., Oishi, S., \& Karler, M. (2006). The meaning in life questionnaire: assessing the presence of and search for meaning in life. Journal of Counseling Psychology, 53, 80-93. https://doi.org/10.1037/0022-0167.53.1.80

Theofilou, P. (2013). Quality of life: definition and measurement. Europe's Journal of Psychology, 9(1), 150- 162. https://doi.org/10.5964/ejop.v9i1.337

WHO Regional Office for Europe https://www.euro.who.int/en/home

Yelizarova, O, Stankevych, T, Parats, A, Antomonov, M, Polka, N, \& Hozak, S (2020). Specific features of the ukrainian urban adolescents' physical activity: A cross-sectional study. Journal of Environmental and Public Health, ID 3404285. https://doi.org/10.1155/2020/3404285

\section{@) $\Theta \Theta \Theta$}

This work is licensed under a Attribution-NonCommercial-NoDerivatives 4.0 International (CC BY-NC-ND 4.0). 